\section{Additional Income for the N.H.S.}

SIR,-I read with interest Professor E. B. SIR,-In a recent letter to The Times ${ }^{1}$ an Shaw's comment (22 February, p. 457) on your recent leading article on children's worms. It may be that the pendulum of medical opinion has swung too far in the direction of discounting symptoms attributable to worm infestation, as the following case may show.

My 4-year-old daughter began having extrem frequency of micturition (every $30 \mathrm{~min}$ ) in March 1974. She had no other symptoms at this time, but as she had had a proved urinary infection aged $2 \frac{1}{2}$ years repeated mid stream specimens of urine were scrutinized. No evidence of infection was found. Her symptoms persisted and after whee months she began having enuresis (she had three months she began having enuresis (she had been dry at night at 2 years old). She also had
bouts of extreme dysuria. After six months with bouts of extreme dysuria. After six months with no real improvement micturating cystography and intravenous pyelography were performed. These investigations and further regular midstream specimens were normal. Nine months after he
frequency first developed she was regularly wettin the bed twice each night After doing so one nigh she woke screaming, and when I was able to examin her I saw, to my astonishment, a threadworm emerging from her urethra.

The family had been treated for threadworms from time to time and the child had had one treatment with viprynium embonate (Vanquin) during the year her symptoms were present. However, it appears that threadworms can inhabit the urethra and bladder and set up a low-grade cystourethritis. Viprynium is non-absorbable, but piperazine is partially excreted through the kidneys. In fact her symptoms have 'now disappeared following a course of piperazine in standard dosage.

In this case considerable morbidity was endured for one year. The diagnosis of threadworms had been discussed at times over the year, but none of us seriously thought that such symptoms as I have described could really be attributed to the in nocuous threadworm.

Department of Paediatrics,

Addenbrooke's Hospital New Site, Cambridge

$\varnothing$

\section{Giardiasis from Russia}

SIR,-Cases of giardiasis among travellers returning from Leningrad have oontinued to be reported during the past year, ${ }^{2}$ and it has been suggested that water is the most likely source of the infection. ${ }^{1}$

One of us recently returned from Leningrad with samples of tap water and these were examined microscopically in Britain 48 hours after being taken from the city's water supply. Giardia lamblia was not seen, either in the trophozoite or in the cyst form. While this does not rule out intermittent contamination of Leningrad's water supply it does mean that other routes of infection, such as the faecal-oral route, should be considered.-We are, etc.,

Academic Division of Medicine,

J. F. MARTIN Royal Infirmary, Royal Infirm
Sheffield

City Hospital,

M. A. MARTIN

1 British Medical fournal, 1974, 2. 394.

2 Shave, P. A., and Thom, B. T., British Medical fournal, 1974, 1, 288 . increase in tobacco duties was advocated to provide additional income for the N.H.S. Yet, allowing for inflation, consumer expenditure on tobacco has increased by only $1.7 \%$ in the years $1962-72 .^{2}$ By comparison, the expenditure on alcoholic drink over the same period has increased by $57 \%$, from $£ 1689 \mathrm{~m}$. to $£ 2661 \mathrm{~m}$. at 1970 prices. Volumetric increase in consumption were as follows: beer $28 \%$, spirits $49 \%$, and wines no less than $111 \% \%^{2}$ Comparing the period 1973-4 with 1972-3, further increases in consumption have occurred of beer by $7 \%$, spirits by $30.5 \%$, and wines by $30 \% .^{3}$ In the period 1972-3 betting receipts of $£ 171 \cdot 3 \mathrm{~m}$. comprised: general betting duty of $51 \%$ ( $£ 1502 \mathrm{~m}$. staked), pool betting duty of $40 \%$ ( $£ 1710 \mathrm{~m}$. staked), and gaming duty of $9 \%$. Over the past five years there has not been any marked alteration in the pro portion of revenues from the three main groups of duties. ${ }^{3}$ Consumer expenditure on tobacco, alcohol, and betting (excluding gaming) totalled $£ 5468 \mathrm{~m}$. in $1972-3$, double the $£ 2731 \mathrm{~m}$. spent on the N.H.S.

These figures, and the rising consumption of alcoholic drink in particular, indicate national priorities quite inappropriate to our hard-pressed times. They also again emphasize that we, as doctors, should not accept any argument that extra finance could not be made available for the N.H.S. If a fall in tobacco consumption would benefit the nation, might not a downturn in alcoholic consumption induced by the requisite fiscal policies be equally beneficial? -I am, etc.,

D. S. ANDREW

Glasgow Institute of Radiotherapeutics,

Western Infirmary, 1 Byrne, P., et al., The Times, 25 February 1975

Central Statistical Office, Annual Abstract of
Statistics No. 110. London, H.M.S.O., 1973. 65th Report of the Commis ioners of Her Majesty's Customs and Excise for the year end-
ing 31 March 1974, H.M.S.O., Cmnd 5789.
London, H.M.S.O., 1974.

\section{A Mortgage Problem}

SIR,-We have a problem which we believe many other doctors who have recently purchased their own premises will also share.

We are proud owners of premises purchased approximately five years ago at a cost of $£ 30000$. Each of us has a mortgage with the General Practice Finance Corporation of $£ 6000$ at $10 \%$ interest per annum The notional rent we receive for our premises is based on the interest charges, and very neatly the two balance. Our might be inclined to think "what a wise investment!" From a retiring partner's point of view it will have been a good investment, of course, but the situation would create all sorts of problems for the remaining partners and even more of a problem for the potential replacement partner.

Let us consider the position of a replacement partner. He would have to find $£ 12000$ as a fifth share. He could probably take over the $£ 6000$ mortgage of the outgoing partner at $10 \%$ interest, provided he could afford to repay in 15 years. Obviously, as time goes by, the shorter the repayment period is going to be; hence the more premises are now worth $£ 60000$, and one

difficult it would be for the new partner to afford the shortened repayment. For the other $£ 6000$ he would have to take out a completely fresh loan from the G.P.F.C. at the current interest rate of $17 \%$. This would involve him in extra interest payments of $£ 1020$ per annum compared with the other partners. The notional rent that this unfortunate would receive is based on the interest payments of the original loan or the district valuer's estimate of a fair rent, whichever is the greater. At the moment, district valuers' estimates of rents are so low that the cost rent is the higher of the two figures.

There is, as far as we can see, only one solution to this problem. A system of cast rents should be paid to each individual doctor according to the amount of interest that the doctor is paying to the G.P.F.C. We have written to our local medical committee about this problem and through your columns would ask any doctor who recog nizes this as his problem also to do the same.-We are, etc.,

K. H. GAY

W. M. T. REES G. J. H. EMRYS-JONES E. N. TURFITT

Padstow, Cornwa!!

\section{Draft Model Contract for G.P.s}

SIR,-I have not had the opportunity of reading full details of the new model contract for general practitioners, but I am alarmed by the principles on which it is based (5 April, p. 49)

Surely this is a repeat of the mistakes made in the Charter for General Practice a few years ago-for example, the suggestion that the doctor who wished to opt out of the out-of-hours commitment could do so if he could find another doctor who would accept his patients for out-of-hours cover was manifestly impracticable. With the new contract, in any area it would only need a few doctors to accept $A / B$ contracts to make it extremely difficult for the remaining doctors to try to work on A contract only. The suggestion that in difficult areas the authority will have the right to insist on an A/B contract means a continuation of the 168-hour week. Are we trying to deprive these areas of medical cover in the years ahead?

A few of the observations made during the General Medical Services Committee's discussion indicate that some of our elected representatives have no idea what most G.P.s think of the present contract. From my discussions with colleagues and by reading the numerous letters in medical publications I feel that most G.P.s are fed up to the teeth with a 24-hour working day. I am aware that there will be cries of loss of independent contractor status, but what is wrong with being an independent contractor for 40 hours a week?

Surely the time has come for G.P.s to move into twentieth-century working conditions. The bulk of our work can, and I feel should, be done during a normal 9 to 5 day by a wide-awake doctor who has not been up for half the night, with an efficiently organized national deputizing service to cover out of hours. The reimbursement for this deputizing work would have to be very high to attract staff. There should also be a fee payable by the patient to deter trivia so 